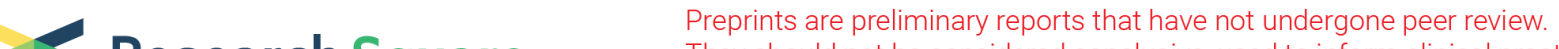 Research Square They should not be considered conclusive, used to inform clinical practice, or referenced by the media as validated information.
}

\section{Asymmetric Effects of Cereals Crops on Agricultural Economic Growth: A Case Study of India}

Surbhi Bansal

Punjab Agricultural University

Pushp Kumar ( $\nabla$ pk27@iitbbs.ac.in )

Indian Institute of Technology Bhubaneswar https://orcid.org/0000-0002-2355-1871

Shan Mohammad

Aligarh Muslim University

Nazim Ali

Aligarh Muslim University

Mohd Arshad Ansari

University of Hyderabad

\section{Research Article}

Keywords: India, NARDL, Rice, Maize, Wheat

Posted Date: June 14th, 2021

DOI: https://doi.org/10.21203/rs.3.rs-616428/v1

License: (c) (1) This work is licensed under a Creative Commons Attribution 4.0 International License. Read Full License

Version of Record: A version of this preprint was published at SN Business \& Economics on November 22nd, 2021. See the published version at https://doi.org/10.1007/s43546-021-00166-2. 
Asymmetric Effects of Cereals Crops on Agricultural Economic Growth: A Case Study of India

\author{
Surbhi Bansal \\ Department of Economics and Sociology \\ Punjab Agricultural University, Ludhiyana Punjab 141001, India \\ $\square$ surbhi-aes@pau.edu \\ ORCID ID: https://orcid.org/0000-0003-3780-9850
}

Pushp Kumar (Corresponding Author)

School of Humanities, Social Sciences, and Management

Indian Institute of Technology Bhubaneswar, Odisha 752050, India

$\square$ pk27@iitbbs.ac.in

ORCID ID: https://orcid.org/0000-0002-2355-1871

\author{
Shan Mohammad \\ Department of Economics \\ Aligarh Muslim University, Aligarh, Uttar Pradesh 202002, India \\ $\square$ shaanecohit@gmail.com \\ Nazim Ali \\ Department of Geography \\ Aligarh Muslim University, Aligarh, Uttar Pradesh 202002, India \\ $\square$ nazimamu.geography@gmail.com \\ ORCID Id: https://orcid.org/0000-0003-4490-6085
}

Mohd Arshad Ansari

School of Economics

University of Hyderabad, Gachibowli, Hyderabad, Telangana, 500046, India

$\square$ 16seph17@uohyd.ac.in

ORCID Id: https://orcid.org/0000-0002-0889-8666 


\title{
Asymmetric Effects of Cereals Crops on Agricultural Economic Growth: A Case Study of India
}

\begin{abstract}
The study explores the asymmetric effects of cereals crops, namely wheat, rice, and maize production on agricultural economic growth in India during 1960-2019. The asymmetric ARDL method is used in this study to analyze the asymmetric relationship between the independent and dependent variables. The findings reveal a link between cereal crop growth and agricultural economic growth. The NARDL findings indicate that positive maize and rice shocks have a considerable short- and long-term influence on agricultural economic growth. In contrast, the positive shock of wheat production is not significant. While the negative shocks of maize, rice and wheat production significantly impact agricultural economic growth. In a nutshell, the study reveals that agriculture growth has an asymmetric relationship with maize, wheat and rice production. The study's findings imply that policymakers should develop longand short-term plans to boost agricultural growth and productivity in order to help farmers.
\end{abstract}

Keywords: India, NARDL, Rice, Maize, Wheat

\section{Introduction}

In the low and middle-income group of countries, agriculture is a source of livelihood as food and raw materials. It provides raw materials for industrial use for hastening up industrialization. Agriculture involves crops production, forestry, livestock husbandry, fishery, man's use and consumption, and processing and marketing of its products (Nesheim et al., 2015; Kanianska, 2016). Moreover, it creates ample employment opportunities for unskilled or rural landless workers, which help poverty alleviation and improve the overall social well-being of the people (Pingali et al., 2019). Likewise, in most countries, earnings from foreign exportation of agricultural materials have played a vital role in dropping the pressure on the balance of payment (Izuchukwu, 2011). Hence, Indian agriculture is considered the base of poverty eradication, economic growth and development of a country.

Agriculture has long been regarded as India's economic backbone. The different agroecological conditions in India have blessed and enriched the country, ensuring food and nutritional security for the majority of the Indian population. India is the world's second-most populated country after China, with a population of 1.36 billion people contributing around $16 \%$ of the national gross domestic product (GDP). More crucially, around two-fifths of the county's population is entirely or heavily reliant on agriculture and related activities for a living (World Bank, 2020). The agriculture sector's contribution to GDP has been declining over time, 
while other sectors, particularly services, have grown. Agriculture contributed 41.31 percent of total GDP in 1960, but by 1990 and 2019 it had dropped to 26.89 percent and 16.01 percent, respectively (World Bank, 2020). Nonetheless, agriculture and related industries continue to be the most important source of income. In 2019, they accounted for 28.63 percent of GDP and 42.6 percent of the country's total employment (World Bank, 2020). India is the world's fifthlargest economy by nominal GDP and third-largest by purchasing power parity, according to World Bank data (2020). (PPP). India is the world's greatest producer of milk, pulses, and jute, as well as wheat, rice, cotton, groundnut, sugarcane, and horticultural crops (FAOSTAT, 2019).

In India, suitable weather conditions and well-arranged irrigation facilities are the reason for the high yield production of cereal crops, i.e., maize, rice, wheat, etc. However, maize is measured as a miracle cereal crop due to its high energy potential and is known as the queen of cereals. Maize is used for a variety of uses in India, including food security, chicken feed, pasture, and industrial raw materials. The production of maize is likely to increase from 10.76 million tonnes to 27.71 million tonnes in the year 1996-97 to 2019-20, respectively (World Bank, 2020). Rice plays a significant role in the agriculture sector. According to World Bank 2020, India is the second-largest rice-producing country in the world after China. The rice output is increased to 177.64 million tonnes from 174.71 million tonnes in the year 2019-20 to 2018-19. In India, rice is considered a staple food crop and grown in the Kharif season. While wheat production is estimated to increase to a record 103.59 million tonnes in 2019-20 from 99.86 million tonnes in the previous year. (World Bank, 2020).

Several studies have been conducted to understand whether agriculture is a viable engine and panacea of the economic prosperity of a country. In response to this, most studies used a time series approach to study the nexus of agricultural production and gross domestic product. (Awokuse and Xie, 2015; Oyakhilomen and Zibah, 2014; Anwer et al.,2015; Awoyemi et al.,2017; Mohammed et al.,2020). Some paper used different cereals crops, namely maize, wheat, rice, cotton by employing the ADRL model to examine the linear association between the independent and dependent variable (Mapfumo,2013; Rehman and Jingdong,2017; Rehman et al., 2017; Rauf et al., 2017; Ullah et al., 2018). Lastly, Ali et al. (2020) exhibited a different perspective by employing a non-linear autoregressive distributed lag model to examine the long run and short-run shock between cereals crops and Pakistan's agricultural gross domestic product. The result depicts that wheat, rice, and maize crop positively impacted agricultural growth. Hence, to the author's knowledge, no work had been conducted yet to employ the non-linear autoregressive distributed lag model technique to check positive and negative shock of cereal crop namely wheat, rice and maize on agricultural growth in India. 
Literature review is presented in Section 2. Section 3 discusses the data and econometrics methods used in the paper. Results and Discussion are presented in Section 4. Lastly, Section 5 reports the Conclusion and Policy Implications of the paper.

\title{
2. Literature Review
}

This section provides the crux of previous studies that directly and indirectly related to understanding the influence of agricultural crop production on the growth of a country's economy.

\section{Insert [Table 1]}

In the context of developing nation, particularly India agriculture growth has been lagging behind as compare to other sector such as manufacturing sector and service. To understand what contributes in the agriculture growth there has been copious studies happened in cross countries to find out the plausible determinant of agriculture growth. Rice output have positive impact on agriculture growth in Pakistan (Rehman et al., 2017; Ali et al., 2020) however, Rehman and Jingdong (2017) conclude that rice production is negatively related with agriculture growth. The wheat and maize production are other important determinant for agriculture growth (Ali et al., 2020). The continuous falling of agriculture share in GDP has compelled policy maker to prioritize this issue as soon as possible and formulate national agriculture policy for increasing share of agriculture in GDP. There is no consensus among determinant of agriculture growth. Against this backdrop, this study has taken all preconceived notion of agriculture growth to into consideration. This study is a novel contribution to see asymmetric relationship among rice production, wheat production maize production and agriculture growth.

\section{Data and Methods}

The study uses the data set contains long annual time series data ranging from 1960 to 2019. The study uses the agricultural gross domestic product (AGDP) as a proxy for agricultural economic growth. To measure the cereal crop, we have taken rice, wheat and maize production. Rice, wheat, and maize are the main cereals crops in India. Trends of the production rice, wheat and maize crops is demonstrated in Figure 1-3. The summary of variables is exhibited in Table 2.

\author{
Insert [Figure 1] \\ Insert [Figure 2] \\ Insert [Figure 3] \\ Insert [Table 2]
}




\section{Nonlinear Autoregressive Distributed Lag Model}

Traditional time series models, such as Johansen-Juselius cointegration and the ARDL model are unable to provide enough information about the non-linear relationship. These models presume that the variables have a linear and systematic connection. Shin et al. (2014) developed the nonlinear ARDL (NARDL) methodology, which is an expanded version of the linear ARDL methodology. Nonlinear ARDL model is used to investigate the asymmetric nonlinearity association among the study variables; it helps to check the probability of the asymmetric impact of explanatory variables' positive and negative shocks on the dependent variable both in the long run and in the short run. Therefore, the NARDL model has been used in this study.

To ensure the asymmetric long-run association between AGDP on cereals crop in India, the NARDL model is written in the following equations:

$A G D P_{t}=\beta_{0}+\beta_{1} M P_{t}+\beta_{2} R P_{t}+\beta_{3} W P_{t}+u_{t}$

Where AGDP, MP, RP, and WP indicate India's agricultural gross domestic product (AGDP), maize, rice, and wheat crop production, respectively, throughout a time period t. The long run coefficients are denoted by $\beta_{\mathrm{i}}$, while the error term is denoted by $\mu_{\mathrm{t}}$. This method was also used in related works by Khan et al. (2019), Ahmad et al. (2020), Ullah et al. (2020), Liao and Baek (2020). Rewrite of equation (1) to express the positive and negative change in maize, wheat and rice production as follows:

$A G D P=\delta_{0}+\delta_{1} M P_{t}^{+}+\delta_{2} M P_{t}^{-}+\delta_{3} R P_{t}^{+}+\delta_{4} R P_{t}^{-}+\delta_{5} W P_{t}^{+}+\delta_{6} W P_{t}^{-}+\mu_{t}$

Where $\delta_{\mathrm{t}}$ indicates coefficients vector for long run parameters to be estimated and $\mathrm{MP}_{\mathrm{t}}^{+}, \mathrm{MP}_{\mathrm{t}}^{-}, \mathrm{RP}_{\mathrm{t}}^{+}, \mathrm{RP}_{\mathrm{t}}^{-}, \mathrm{WP}_{\mathrm{t}}^{+}$and $\mathrm{WP}_{\mathrm{t}}^{-}$denote the partial sum of positive (negative) changes in $\mathrm{MP}, \mathrm{RP}$ and WP, respectively. Following the value of $\mathrm{MP}_{\mathrm{t}}^{+}, \mathrm{MP}_{\mathrm{t}}^{-}, \mathrm{RP}_{\mathrm{t}}^{+}, \mathrm{RP}_{\mathrm{t}}^{-}, \mathrm{WP}_{\mathrm{t}}^{+}$and $\mathrm{WP}_{\mathrm{t}}^{-}$ can be framed through the following Equations.

$$
\begin{aligned}
M P^{+} & =\sum_{i=1}^{t} \Delta M P_{i}^{+}=\sum_{i=1}^{t} \max \left(\Delta M P_{i}, 0\right) \\
M P^{-} & =\sum_{i=1}^{t} \Delta M P_{i}^{-}=\sum_{i=1}^{t} \min \left(\Delta M P_{i}, 0\right) \\
R P^{+} & =\sum_{i=1}^{t} \Delta R P_{i}^{+}=\sum_{i=1}^{t} \max \left(\Delta R P_{i}, 0\right) \\
R P^{-} & =\sum_{i=1}^{t} \Delta R P_{i}^{-}=\sum_{i=1}^{t} \min \left(\Delta R P_{i}, 0\right)
\end{aligned}
$$




$$
\begin{aligned}
& W P^{+}=\sum_{i=1}^{t} \Delta W P_{i}^{+}=\sum_{i=1}^{t} \max \left(\Delta W P_{i}, 0\right) \\
& W P^{-}=\sum_{i=1}^{t} \Delta W P_{i}^{-}=\sum_{i=1}^{t} \min \left(\Delta W P_{i}, 0\right)
\end{aligned}
$$

As set out in Shin et al. (2014) and Pesaran et al. (2001), we substitute equation 2 into equation 1 for estimating the asymmetric long-run and short-run relationship among study variables, we specify the equation as follow:

$$
\begin{aligned}
\Delta A G D P_{t}= & \vartheta_{0}+\vartheta_{1} A G D P_{t-1}+\vartheta_{2}^{+} M P_{t-1}^{+}++\vartheta_{3}^{-} M P_{t-1}^{-}++\vartheta_{4}^{+} R P_{t-1}^{+}++\vartheta_{5}^{-} R P_{t-1}^{-}+ \\
& \vartheta_{6}^{+} W P_{t-1}^{+}+\vartheta_{7}^{-} W P_{t-1}^{-}+\sum_{i=1}^{k} \omega_{i} \Delta A G D P_{t-1}+\sum_{i=1}^{p} \varphi_{2 i}^{+} \Delta M P_{t-1}^{+}+ \\
& \sum_{i=1}^{q} \varphi_{3 i}^{-} \Delta M P_{t-1}^{-}+\sum_{i=1}^{r} \varphi_{4 i}^{+} \Delta R P_{t-1}^{+}+\sum_{i=1}^{s} \varphi_{5 i}^{-} \Delta R P_{t-1}^{-}+\sum_{i=1}^{a} \varphi_{6 i}^{+} \Delta W P_{t-1}^{+}+ \\
& \sum_{i=1}^{b} \varphi_{7 i}^{-} \Delta W P_{t-1}^{-}+\mu_{t}
\end{aligned}
$$

We extend the single equation asymmetric model specified in equation (3) with the introduction of an error correction model (ECM).

$$
\begin{aligned}
\Delta A G D P_{t}=\vartheta_{0} & +\vartheta_{1} A G D P_{t-1}+\vartheta_{2}^{+} M P_{t-1}^{+}++\vartheta_{3}^{-} M P_{t-1}^{-}++\vartheta_{4}^{+} R P_{t-1}^{+}++\vartheta_{5}^{-} R P_{t-1}^{-}+ \\
& \vartheta_{6}^{+} W P_{t-1}^{+}+\vartheta_{7}^{-} W P_{t-1}^{-}+\sum_{i=1}^{k} \omega_{i} \Delta A G D P_{t-1}+\sum_{i=1}^{p} \varphi_{2 i}^{+} \Delta M P_{t-1}^{+}+ \\
& \sum_{i=1}^{q} \varphi_{3 i}^{-} \Delta M P_{t-1}^{-}+\sum_{i=1}^{r} \varphi_{4 i}^{+} \Delta R P_{t-1}^{+}+\sum_{i=1}^{s} \varphi_{5 i}^{-} \Delta R P_{t-1}^{-}+\sum_{i=1}^{a} \varphi_{6 i}^{+} \Delta W P_{t-1}^{+}+ \\
& \sum_{i=1}^{b} \varphi_{7 i}^{-} \Delta W P_{t-1}^{-}+\omega E C M_{t-1}+\mu_{t}
\end{aligned}
$$

In equation 4 , where $\Delta^{\prime} s$ exhibits the differenced variables in time period $\mathrm{k}, \mathrm{p}, \mathrm{q}, \mathrm{r}, \mathrm{s}, \mathrm{a}$, and b symbolize the respective lags orders. $\vartheta=\vartheta_{1}, \vartheta_{2}^{+}, \vartheta_{3}^{-}, \vartheta_{4}^{+}, \vartheta_{5}^{-}, \vartheta_{6}^{+}, \vartheta_{7}^{-}$specify the coefficients of the long-term positive and negative variations of maize, rice and wheat on AGDP. While $\sum_{i=1}^{p} \varphi_{2 i}^{+} \Delta M P_{t-1}^{+}+\sum_{i=1}^{q} \varphi_{3 i}^{-} \Delta M P_{t-1}^{-}, \sum_{i=1}^{r} \varphi_{4 i}^{+} \Delta R P_{t-1}^{+}+\sum_{i=1}^{s} \varphi_{5 i}^{-} \Delta R P_{t-1}^{-}$,

$\sum_{i=1}^{a} \varphi_{6 i}^{+} \Delta W P_{t-1}^{+}+\sum_{i=1}^{b} \varphi_{7 i}^{-} \Delta W P_{t-1}^{-}$and express short term positive and negative effects of maize, rice as well as wheat crop production on AGDP, respectively. Additionally, the longterm consequence of positive and negative variations on the AGDP can be scrutinized as $\gamma_{1}=$ $-\frac{\vartheta_{2}}{\vartheta_{1}}, \gamma_{2}=-\frac{\vartheta_{3}}{\vartheta_{1}}, \gamma_{3}=-\frac{\vartheta_{4}}{\vartheta_{1}}, \gamma_{4}=-\frac{\vartheta_{5}}{\vartheta_{1}}, \gamma_{5}=-\frac{\vartheta_{6}}{\vartheta_{1}}, \gamma_{6}=-\frac{\vartheta_{7}}{\vartheta_{1}}$, respectively.

As discussed earlier, NARDL model involves numerous steps, i.e., it is vital step to check to stationarity of study variables that none of variable integrated beyond of second order. So, it is compulsory to scrutinize the unit root properties of the variables used in the study. According 
to Ouattara (2004), consisting a variable with more than 1 order of integrated yield spurious results. Thus, before applying the NARDL model, we employ Augmented Dickey-Fuller (ADF) and Phillips-Perron (PP) unit root tests to inspect the order integration of variables.

After that, we examine the presence of long-term asymmetric among dependent and independent variables with the testing of following hypothesis

$$
\begin{aligned}
& H_{0}=\vartheta_{1}=\vartheta_{2}^{+}=\vartheta_{3}^{-}=\vartheta_{4}^{+}=\vartheta_{5}^{-}=\vartheta_{6}^{+}=\vartheta_{7}^{-} \\
& H_{1}=\vartheta_{1} \neq \vartheta_{2}^{+} \neq \vartheta_{3}^{-} \neq \vartheta_{4}^{+} \neq \vartheta_{5}^{-} \neq \vartheta_{6}^{+} \neq \vartheta_{7}^{-}
\end{aligned}
$$

We use many diagnostic tests to assess the robustness of our results after determining the presence of long- and short-term asymmetric effects on research variables. To assess parameter constancy, we use the Breusch-Godfrey LM test for serial correlation, the Breusch-PaganGodfrey test for heteroscedasticity, and the CUSUM and CUSUMQ tests suggested by Brown et al (1975).

\section{Results and Discussion}

Before interpreting the results, it is important to describe the descriptive statistics of the variable that was utilised in the study. We have shown the results of descriptive statistics in Table-3. Agriculture growth mean is 183.236 billion while its maximum and the minimum value are 393.724 and 77.454 respectively standard value is 89.044 . Wheat production's mean and standard deviation value in a million tonnes is 52.265 and 27.934 , whereas maize production's standard deviation and mean value are 6.973 and 11.472 million tonnes. Rice production has got a mean value of 105.269. The Jarque-Bera test confirms the normality of residuals

\section{Insert [Table 3]}

Table 4 shows the results of the unit root tests, namely ADF and PP. It is necessary to assess the order of integration among variables using the proper unit root test before predicting the elasticities. It is also pertinent to confirm the stationary properties since the cointegration technique and causality estimation depends upon integration among variables. The ADF test results indicate that agriculture growth and rice production are stationary at a level while maize production and wheat production are non-stationary at a level. However, all the variables become stationary at first difference. Hence a common order of integration is confirmed from the ADF test. However, we have applied another test of stationary. The t-test statistics are corrected non-parametrically using the Phillips-Perron (PP) test. This test is unaffected by 
nonspecific autocorrelation and heteroscedasticity in the test equation's disturbance process. Except for wheat production, the findings of the PP test show that all variables are stationary at a certain level. At first difference, however, they all become immobile. At the second difference, it has also been assured that none of the variables are stationary.

\section{Insert [Table 4]}

After confirming the order of integration, it is pertinent to evaluate the cointegrating properties among variables. To check the presence of cointegration among variables, we have applied the Bounds cointegration test. The results of this test indicate that there is cointegration among variables. The F- statistics value is above the upper bound value, ensuring a long-run association among variables (Table 5).

\section{Insert [Table 5] \\ Insert [Table 6]}

In Table 6, we discuss the long-run asymmetric between a dependent variable and independent variables. The occurrence of positive and negative shocks of maize production, wheat production, and rice production on agriculture growth are captured through the NARDL econometric model. The positive shock of maize production has significantly influenced agriculture growth in the long run and short run, with the coefficient value 0.330 and 0.150 , respectively, at a $1 \%$ level of significance. The positive shock of maize production implies that a rise in maize production will significantly contribute to agriculture growth positvely. The maize negative shock coefficient value is 0.342 . It implies that agricultural economic growth falls by $0.342 \%$ with a $1 \%$ fall in $\mathrm{MP}^{-}$in India. We observed that agriculture growth responds more rapidly to a decrease in maize production than an increase in maize production. Therefore, it indicates that a reduction of maize production automatically leads to a decline in agriculture growth. Hence, it gives an important message to the policymaker to make a policy for the negative shock it can combat whenever there is a decrease in the production of maize.

At a $1 \%$ significance level, the positive and negative shock coefficient values for rice production are 0.771 and 0.933 , respectively. The negative shock of rice production is more dominant than the positive shock of the same. The negative shock's coefficient sign is positive, saying that rice production decreases will reduce agriculture growth. In a nutshell, the intrinsic non-linearity between positive and negative shocks of rice production and agriculture is indispensable for policy formulation. The positive and negative shocks in the short run are also significant at a $1 \%$ significance level.

The wheat production's positive shock value has a neutral impact on agriculture growth, while its negative shock significantly impacts agriculture growth. The value of wheat production 
coefficient for negative shocks are 0.558 while the positive shocks are 0.095 but it is statistically insignificant. This implies that production of wheat has negative linkage with AGDP in the long run. The decrease in the quantity of wheat production is because of certain agricultural practices often lead to decreasing production from crops, these include irrigation facility, seed, machinery, and fertilizers. Moreover, for optimum wheat growth, it requires mild winters but it get impacted due to intense heat.

\section{Insert [Table 7]}

Table 7 shows the presence of asymmetry in the long run among dependent and independent variables. The results indicate that there is a presence of asymmetry among maize production, wheat production, rice production, and agriculture growth, while in the short run, maize production and rice production shows no asymmetry with agricultural growth.

\section{Insert [Table 8] \\ Insert [Figure 4] \\ Insert [Figure 5]}

The diagnostic test results are presented in Table-8. The LM and Breusch-Pagan-Godfrey tests have p-values of 0.312 and 0.302 , showing that the model is free of severe serial correlation issues and heteroscedasticity. Any statistical study must be checked for robustness in order to ensure parameter stability in the model. As a result, the CUSUM and CUSUMSQ parameter stability tests were used. After estimating the long-run and short-run, we may check the model's stability. In contrast to the break-point, the statistics of CUSUM and CUSUMSQ are updated recursively. If the CUSUM and CUSUMSQ lines stay inside the upper and lower bounds of the CUSUM and CUSUMSQ graph, the predicted parameter is stable. The CUSUM and CUSUMSQ graph shows that the blue line remains inside the red line of the upper and lower bound, which confirmed the stability of the model.

\section{Insert [Table 9]}

The asymmetric causality between dependent and independent variables can be seen in Table 9. In this section, we interpreted the results of asymmetric causal linkages between dependent and independent variables. The Granger causality test is being applied for causality analysis. It is concluded that the positive shock of maize production has a significant impact on agriculture growth. However, agriculture growth does not Granger cause maize production. The negative shock in maize production did not negatively impact or a neutral effect on agriculture growth. Moreover, agriculture growth does not Granger causes a negative shock of maize production. There is a unidirectional causal relationship that exists between maize production and agriculture growth. Therefore, policy implication needs to increase maize's production for 
boosting agriculture growth by providing input subsidies on seeds and fertilizer. The positive shock of wheat production does not Granger cause agriculture growth. We have rejected the null hypothesis, which states that wheat production does not granger cause agriculture growth.

Agricultural expansion has also had a favourable and considerable impact on wheat production. Agriculture growth has created bad shocks in wheat output, and agriculture growth has generated adverse shocks in wheat output. The positive Agricultural expansion has also had a favourable and considerable impact on wheat production. Agriculture growth has created bad shocks in wheat output, and agriculture growth has generated adverse shocks in wheat output. shock of rice production does not granger cause agriculture growth, while its negative shock significantly impacts agriculture growth. There is no bidirectional causality exist between rice production and agriculture growth. Moreover, we can say that causality runs from rice production to agriculture growth. There is a presence of unidirectional causality between maize production and wheat production. We have found bidirectional causality between wheat's negative shock and maize positive shock.

\section{Conclusion and Policy Implications}

During the period 1960-2019 in India, this study looked at the relationship between agricultural economic growth and cereal crop production, specifically maize, rice, and wheat. We look into the potential of asymmetric effects of positive and negative wheat, rice, and maize production shocks on India's agricultural economic growth. The variables are stationary at either the level or first difference, according to the ADF and PP unit root tests. Bounds cointegration establish the long-run relationship between cereals crops and agricultural economic growth. Detrimental shocks in wheat output have a negative impact on agricultural economic growth, according to the NARDL model. While the increase in wheat production is beneficial in the short term, it has little long-term impact on agricultural economic growth. It might be due to declining the total factor productivity over the years due to stagnant productivity with overuse of chemical fertilizers. Input scarcity, inconsistent power supply, temperature fluctuations during growth, high input costs, and limited access to seed of freshly released varieties are among the issues. The effects of positive and negative shocks in rice production have a significant impact on agricultural economic growth in the short and long term. Since the government provides subsidies in inputs, high demand at the domestic level and high consumption. At the same time, India stands second for the production of rice after China. Conversely, regarding maize production, it plays an important role in attaining long-run agricultural economic growth. So 
the government should focus on expand the production of maize crop by providing more subsidies for its production.

The result of the NARDL model recommended that crop production have a robust both in short- and long-term relationship with the agricultural economic growth of India. Thus this study suggested that to boost the export of agricultural products by launch new rural development projects. Improve crop productivity with the introduction of new agriculture technologies and the provision of good seeds and other agriculture inputs. Government should also focus on proper training to farmers about the usage of fertilizers and chemical sprays on food crops, adequate storing marketing, insurance, irrigation facilities, subsidies on farm machinery etc. Since there exist a long run relationship between GDP and agriculture, more investments from both the private and public sector should be undertaken to enhance agricultural productivity towards economic growth.

\section{Declaration}

Availability of data and materials: Data will be made available upon request

Competing interests: We do not have any conflict of interest

Funding: There is no funding to report

Authors' contributions: Surbhi Bansal and Pushp Kumar have done the Literature Review, Data Analysis and Results Reporting. Shan Mohammad and Nazim Ali have compiled the Introduction and Discussion of the Results. Pushp Kumar and Mohd Arshad Ansari have done the overall formatting of the paper. All authors have read and approved the manuscript.

Acknowledgements: Not Applicable

\section{Reference}

Ahmad M, Khattak SI, Khan S, Rahman ZU (2020) Do aggregate domestic consumption spending \& technological innovation affect industrialization in South Africa? An application of linear \& nonlinear ARDL models. Journal of Applied Economics, 23(1),44-65.

Ali, I., Khan, I., Ali, H., Baz, K., Zhang, Q., Khan, A., \& Huo, X. (2020). Does Cereal crops asymmetrically affect Agriculture gross domestic product in Pakistan? Using NARDL model approach. Ciência Rural, 50(5), 1-12. 
Anwer, M., Farooqi, S., \& Qureshi, Y. (2015). Agriculture sector performance: An analysis through the role of agriculture sector share in GDP. Journal of Agricultural Economics, Extension and Rural Development, 3(3), 270-275.

Awokuse, T. O., \& Xie, R. (2015). Does agriculture really matter for economic growth in developing countries?. Canadian Journal of Agricultural Economics/Revue canadienne d'agroeconomie, 63(1), 77-99.

Awoyemi, B. O., Afolabi, B., \& Akomolafe, K. J. (2017). Agricultural Productivity and Economic Growth: Impact Analysis from Nigeria. Scientific Research Journal (SCIRJ), 5(10), 1-7.

Brown RL, Durbin J, Evans JM (1975) Techniques for testing the constancy of regression relationships over time. Journal of the Royal Statistical Society, Series B, 37,149-192.

FAOSTAT (2019). Food and Agriculture Organization of the United Nations, Statistics Division, 2019.

Hussain, A., \& Ajmair, M. (2016). Impact of Major Crops on GDP (Pakistan Case). International Journal of Science and Research, 5(4), 370-373.

Izuchukwu, O. (2011). Analysis of the contribution of agricultural sector on the Nigerian economic development. World review of business research, 1(1), 191-200.

Johansen, S., \& Juselius, K. (1990). Maximum likelihood estimation and inference on cointegration - with appucations to the demand for money. Oxford Bulletin of Economics and statistics, 52(2), 169-210. https://doi.org/10.1111/j.1468-0084.1990.mp52002003.x

Kanianska, R. (2016). Agriculture and its impact on land-use, environment, and ecosystem services. Landscape ecology-The influences of land use and anthropogenic impacts of landscape creation, 1-26.

Khan Z, Sisi Z, Siqun Y (2019) Environmental regulations an option: asymmetry effect of environmental regulations on carbon emissions using non-linear ARDL. Energy Sources, Part A: Recovery, Utilization, and Environmental Effects, 41(2),137-155.

Kulshrestha, D., \& Agrawal, K. K. (2019). An econometric analysis of agricultural production and economic growth in India. Indian Journal of Marketing, 49(11), 56-65.

Liao, X., \& Baek, J. (2020). Analysing the Asymmetric Effects of Crude Oil Price Changes on China's Petroleum Product Prices. The Singapore Economic Review, 120. https://doi.org/10.1142/S021759081950070X

Mohammed, T., Damba, T., \& Amikuzuno, J. (2020). Agricultural Output and Economic Growth Nexus in Ghana. International Journal of Irrigation and Agricultural Development (IJIRAD), 4(1), 211-220. 
Mapfumo, A. (2013). An econometric analysis of the relationship between agricultural production and economic growth in Zimbabwe. Russian Journal of Agricultural and Socio-Economic Sciences, 23(11), 11-15.

Nesheim, M. C., Oria, M., Yih, P. T., on Agriculture, B., Resources, N., \& National Research Council. (2015). Social and Economic Effects of the US Food System. In A Framework for Assessing Effects of the Food System. National Academies Press (US).

Ouattara, B. (2004). Foreign aid and fiscal policy in Senegal (pp. 262-267). Manchester: Mimeo University of Manchester.

Oyakhilomen, O., \& Zibah, R. G. (2014). Agricultural production and economic growth in Nigeria: Implication for rural poverty alleviation. Quarterly Journal of International Agriculture, 53(892-2016-65234), 207-223.

Pattanayak, U., \& Mallick, M. (2017). Agricultural Production and Economic Growth in India: An Econometric Analysis. Asian Journal of Multidisciplinary Studies, 5(3), 62-66.

Pesaran MH, Shin Y, Smith RJ (2001) Bounds testing aproaches to the analysis of level relationships. Journal of Applied Econometrics,16(3),289-326

Pingali, P., Aiyar, A., Abraham, M., \& Rahman, A. (2019). Rural Livelihood Challenges: Moving out of Agriculture. In Transforming Food Systems for a Rising India (pp. 47-71). Palgrave Macmillan, Cham.

Rauf, A., Liu, X., Sarfraz, M., Shehzad, K., \& Amin, W. (2017). Economic stance of wheat crop yield in Pakistan: application of ARDL bound testing model. Journal of Global Innovations in Agricultural and Social Sciences, 5, 175-180.

Raza, S. A., Ali, Y., \& Mehboob, F. (2012). Role of Agriculture in Economic Growth of Pakistan. International Research Journal of Finance and Economics, (83),180-186

Rehman, A., \& Jingdong, L. (2017). An econometric analysis of major Chinese food crops: An empirical study. Cogent Economics \& Finance, 5(1), 1323372.

Rehman, A., Jingdong, L., Chandio, A. A., Shabbir, M., \& Hussain, I. (2017). Economic outlook of rice crops in Pakistan: A time series analysis (1970-2015). Financial innovation, 3(1), 1-9.

Shin Y, Yu B, Greenwood-Nimmo M (2014) Modelling asymmetric cointegration and dynamic multipliers in a nonlinear ardl framework. In: Horrace W, Sickles R (eds) The Festschrift in Honor of Peter Schmidt: Econometric Methods and Applications. Springer, New York, pp 281-314

Ullah, A., Khan, D., \& Zheng, S. (2018). Testing long-run relationship between agricultural gross domestic product and fruits production: evidence from Pakistan. Ciência Rural, 48(5),1-12. 
Table 1. Summary of Review of Literature

\begin{tabular}{|c|c|c|c|c|}
\hline Author(s) & Time & Countries & $\begin{array}{l}\text { Econometric } \\
\text { Model }\end{array}$ & Results \\
\hline $\begin{array}{l}\text { Rehman and Jingdong } \\
\text { (2017) }\end{array}$ & $1980-2015$ & China & $\begin{array}{l}\text { Johansen } \\
\text { Cointegration } \\
\text { model }\end{array}$ & $\begin{array}{l}\text { Output of Wheat, cotton , sugarcane, corn } \\
\text { and tubers = +AGDP } \\
\text { Output of Rice = - AGDP }\end{array}$ \\
\hline Rehman et al (2017) & $1970-2015$ & Pakistan & $\begin{array}{l}\text { Johansen } \\
\text { cointegration } \\
\text { test }\end{array}$ & Rice output and cultivated area $=+$ AGDP \\
\hline Ali et al (2020) & $1970-2017$ & Pakistan & NARDL & $\begin{array}{l}\text { Rice, maize, wheat }=+ \text { AGDP } \\
\text { Rice, maize }=>\text { AGDP }\end{array}$ \\
\hline Mohammed et al (2020) & $1960-2016$ & Ghana & $\begin{array}{l}\text { Johannsen } \\
\text { cointegration }\end{array}$ & Agricultural output $=+$ Economic growth \\
\hline Anwer et al (2015) & $1975-2012$ & Pakistan & OLS & Agriculture sector $=+$ GDP \\
\hline $\begin{array}{l}\text { Awokuse and Xie } \\
(2015)\end{array}$ & $1980-2011$ & $\begin{array}{l}3 \text { Sub-Saharan Africa, } 3 \\
\text { Asia and } 3 \text { Latin America }\end{array}$ & ARDL & $\begin{array}{l}\text { agriculture could be an engine of economic } \\
\text { growth, the impact varies across countries }\end{array}$ \\
\hline $\begin{array}{l}\text { Hussain and Ajmair } \\
\text { (2016) }\end{array}$ & $1980-2010$ & Pakistan & OLS & $\begin{array}{l}\text { Maize, wheat, rice and cotton }=+ \text { GDP } \\
\text { Sugarcane }=- \text { GDP }\end{array}$ \\
\hline Raza et al(2012) & $1980-2010$ & Pakistan & OLS & Rice, wheat, cotton $=+$ economic growth \\
\hline Awoyemi et al (2017) & $1981-2015$ & Nigeria & $\begin{array}{l}\text { Johansen } \\
\text { cointegration }\end{array}$ & $\begin{array}{l}\text { Agricultural productivity }=+ \text { economic } \\
\text { growth }\end{array}$ \\
\hline $\begin{array}{l}\text { Kulshrestha and } \\
\text { Agrawal (2019) }\end{array}$ & $1961-2017$ & India & $\begin{array}{l}\text { Johansen } \\
\text { cointegration }\end{array}$ & $\begin{array}{l}\text { Rice and pulses }=+ \text { GDP } \\
\text { Wheat and cotton lint=-GDP }\end{array}$ \\
\hline $\begin{array}{l}\text { Pattanayak and Mallick } \\
\text { (2017) }\end{array}$ & $1991-2012$ & India & $\begin{array}{l}\text { Johansen } \\
\text { cointegration }\end{array}$ & $\begin{array}{l}\text { Tea, cereals and tobacco =+ GDP growth } \\
\text { Coffee and sugarcane production=-GDP } \\
\text { growth }\end{array}$ \\
\hline $\begin{array}{l}\text { Oyakhilomen and } \\
\text { Zibah (2014) }\end{array}$ & $1970-2011$ & Nigeria & ARDL & Agricultural Production=+Economic growth \\
\hline Mapfumo (2013) & $1980-2010$ & Zimbabwe & $\begin{array}{l}\text { Johansen } \\
\text { cointegration }\end{array}$ & $\begin{array}{l}\text { Tobacco and cotton }=+ \text { Real GDP } \\
\text { Coffee }=- \text { Real GDP }\end{array}$ \\
\hline Rauf et al (2017) & 1981 to 2015 & Pakistan & ARDL & Wheat crop area =+ agril GDP \\
\hline
\end{tabular}




\begin{tabular}{|l|l|l|l|l|}
\hline & & & & Wheat crop yield and fertilizer =-Agril GDP \\
\hline Ullah et al (2018) & $1961-2015$ & Pakistan & ARDL & Mango, apple, peach production =+ AGDP \\
\hline
\end{tabular}

Note $=>$ Unidirectional relationship, + positive impact, - negative impact, the Kwiatkowski-Phillips- Schmidt-Shin (KPSS) test, ADF Augmented Dickey

Fuller test, PP Phillips-Perron, ARDL Autoregressive Distributed lag model, NARDL Nonlinear Autoregressive Distributed lag model, 
Table 2. Description of Variables

\begin{tabular}{|l|l|l|l|}
\hline Variable & Symbol & Unit & Source \\
\hline Agricultural Growth & $\ln$ AGDP & $\begin{array}{l}\text { Constant billion } \\
\text { 2010 US \$ }\end{array}$ & World Bank \\
\hline Wheat Production & $\ln \mathrm{WP}$ & million tonnes & FAO \\
\hline Rice Production & $\operatorname{lnRP}$ & million tonnes & FAO \\
\hline Maize Production & $\operatorname{lnMP}$ & million tonnes & FAO \\
\hline
\end{tabular}

Table 3. Descriptive Statistics

\begin{tabular}{|l|l|l|l|l|}
\hline & AGDP & MP & RP & WP \\
\hline Mean & 183.236 & 11.472 & 105.269 & 52.265 \\
\hline Median & 160.790 & 8.884 & 109.001 & 54.110 \\
\hline Maximum & 393.724 & 28.753 & 177.645 & 103.596 \\
\hline Minimum & 77.454 & 4.312 & 45.657 & 9.853 \\
\hline Std. Dev. & 89.044 & 6.973 & 38.846 & 27.934 \\
\hline Skewness & 0.707 & 1.066 & 0.110 & 0.070 \\
\hline Kurtosis & 2.423 & 2.871 & 1.738 & 1.833 \\
\hline Jarque-Bera & 5.739 & 11.210 & 4.036 & 3.397 \\
\hline Probability & 0.087 & 0.42 & 0.133 & 0.183 \\
\hline Observations & 59 & 59 & 59 & 59 \\
\hline
\end{tabular}

Table 4. Unit Root Test Results

\begin{tabular}{|l|l|l|l|l|}
\hline & \multicolumn{2}{|c|}{ ADF Test } & \multicolumn{2}{c|}{ PP Test } \\
\hline Variables & $\mathrm{I}(0)$ & $\mathrm{I}(1)$ & $\mathrm{I}(0)$ & $\mathrm{I}(1)$ \\
\hline $\ln \mathrm{AGDP}$ & $-5.610 * * *$ & $-11.752 * * *$ & $-5.559 * * *$ & $-23.737 * * *$ \\
\hline $\ln \mathrm{MP}$ & -1.432 & $-9.879 * * *$ & $-4.458 * * *$ & $-21.890 * * *$ \\
\hline $\ln \mathrm{RP}$ & $-3.491 *$ & $-9.127 * * *$ & $-5.890 * * *$ & $-27.918 * * *$ \\
\hline $\ln \mathrm{WP}$ & -1.831 & $-8.878 * * *$ & -1.685 & $-8.894 * * *$ \\
\hline
\end{tabular}

Note: $* * *<0.01, * *<0.05$, and $*<0.1$

Table 5. Bounds Cointegration Test

\begin{tabular}{|l|l|l|l|l|}
\hline Test Statistic & Value & Significance level & LB & UB \\
\hline F-statistic & 16.508 & $1 \%$ & 1.990 & 2.940 \\
\hline & & $5 \%$ & 2.270 & 3.280 \\
\hline & & $10 \%$ & 2.880 & 3.990 \\
\hline
\end{tabular}


Table 6. NARDL Model Results

\begin{tabular}{|l|l|l|l|l|}
\hline Variable & Coefficient & Std. Error & t-Statistic & Prob. \\
\hline $\ln M P^{+}$ & 0.330 & 0.056 & 5.896 & 0.000 \\
\hline $\ln M P^{-}$ & 0.342 & 0.079 & 4.316 & 0.000 \\
\hline $\ln R P^{+}$ & 0.771 & 0.147 & 5.228 & 0.000 \\
\hline $\ln R P^{-}$ & 0.933 & 0.165 & 5.636 & 0.000 \\
\hline $\ln W P^{+}$ & 0.095 & 0.063 & -1.513 & 0.137 \\
\hline $\ln W P^{-}$ & 0.558 & 0.197 & -2.835 & 0.007 \\
\hline Constant & 25.102 & 0.044 & 575.125 & 0.000 \\
\hline ECM & -0.413 & 0.034 & -12.335 & 0.000 \\
\hline$\Delta \ln M P^{+}$ & 0.150 & 0.041 & 3.627 & 0.001 \\
\hline$\Delta \ln M P^{-}$ & -0.017 & 0.059 & -0.292 & 0.772 \\
\hline$\Delta \ln R P^{+}$ & 0.523 & 0.083 & 6.333 & 0.000 \\
\hline$\Delta \ln R P^{-}$ & 0.387 & 0.057 & 6.811 & 0.000 \\
\hline$\Delta \ln W P^{+}$ & -0.228 & 0.082 & -2.764 & 0.009 \\
\hline$\Delta \ln W P^{-}$ & 0.016 & 0.121 & 0.131 & 0.897 \\
\hline R-squared & 0.879 & & & \\
\hline Adjusted R-squared & 0.872 & & & \\
\hline Durbin-Watson Statistics & 1.865 & & & \\
\hline
\end{tabular}

Table 7. Testing the Presence of Asymmetries

\begin{tabular}{|c|c|c|c|c|}
\hline Variable & & F-statistics & P-value & Presence of Asymmetry \\
\hline & \multicolumn{2}{|l|}{ Long run Asymmetry } & & \\
\hline $\operatorname{lnMP}$ & & 19.984 & 0.000 & Yes \\
\hline $\operatorname{lnWP}$ & & 3.748 & 0.063 & Yes \\
\hline $\operatorname{lnRP}$ & & 3.953 & 0.053 & Yes \\
\hline & \multicolumn{2}{|l|}{ Short run Asymmetry } & & \\
\hline $\operatorname{lnMP}$ & & 0.131 & 0.720 & No \\
\hline $\operatorname{lnWP}$ & & 18.127 & 0.000 & Yes \\
\hline $\operatorname{lnRP}$ & & 0.009 & 0.924 & No \\
\hline
\end{tabular}

Table 8. Diagnostic Tests

\begin{tabular}{|l|l|l|}
\hline Tests & Statistics & Probability \\
\hline LM for serial correlation & 0.312 & 0.733 \\
\hline BPG for heteroscedasticity & 0.302 & 0.977 \\
\hline CUSUM & Stable & \\
\hline CUSUM Square & Stable & \\
\hline
\end{tabular}


Table 9. Granger Causality Test

\begin{tabular}{|c|c|c|}
\hline Null Hypothesis: & F-Statistic & Prob. \\
\hline $\operatorname{lnMP}^{+} \nRightarrow \mathrm{LNAG}$ & 3.029 & 0.057 \\
\hline $\ln \mathrm{AGDP} \nRightarrow \ln \mathrm{MP}^{+}$ & 1.321 & 0.276 \\
\hline $\ln \mathrm{MP}^{-} \nRightarrow \ln \mathrm{AGDP}$ & 1.037 & 0.362 \\
\hline $\ln \mathrm{AGDP} \nRightarrow \ln \mathrm{MP}^{-}$ & 0.066 & 0.936 \\
\hline $\ln \mathrm{WP}^{+} \nRightarrow \ln \mathrm{AGDP}$ & 1.013 & 0.370 \\
\hline $\ln \mathrm{AGDP} \nRightarrow \ln \mathrm{WP}^{+}$ & 20.113 & 0.000 \\
\hline $\operatorname{lnWP^{-}} \nRightarrow \ln \mathrm{AGDP}$ & 4.220 & 0.020 \\
\hline $\ln \mathrm{AGDP} \nRightarrow \ln \mathrm{WP}^{-}$ & 13.022 & 0.000 \\
\hline $\operatorname{lnRP}^{+} \nRightarrow \ln \mathrm{AGDP}$ & 0.750 & 0.477 \\
\hline $\ln \mathrm{AGDP} \nRightarrow \ln \mathrm{RP}^{+}$ & 3.500 & 0.038 \\
\hline $\operatorname{lnRP^{-}} \nRightarrow \ln A G D P$ & 2.762 & 0.073 \\
\hline $\ln \mathrm{AGDP} \nRightarrow \ln \mathrm{RP}^{-}$ & 0.657 & 0.523 \\
\hline $\ln \mathrm{MP}^{-} \nRightarrow \ln \mathrm{MP}^{+}$ & 8.052 & 0.001 \\
\hline $\ln \mathrm{MP}^{+} \nRightarrow \ln \mathrm{MP}^{-}$ & 2.302 & 0.110 \\
\hline $\ln \mathrm{WP}^{+} \nRightarrow \ln \mathrm{MP}^{+}$ & 1.936 & 0.155 \\
\hline $\ln \mathrm{MP}^{+} \nRightarrow \ln \mathrm{WP}^{+}$ & 6.248 & 0.004 \\
\hline $\ln \mathrm{WP}^{-} \nRightarrow \ln \mathrm{MP}^{+}$ & 3.770 & 0.030 \\
\hline $\operatorname{lnMP^{+}} \nRightarrow \ln \mathrm{WP}^{-}$ & 5.181 & 0.009 \\
\hline $\ln \mathrm{RP}^{+} \nRightarrow \ln \mathrm{MP}^{+}$ & 1.865 & 0.165 \\
\hline $\operatorname{lnMP}^{+} \nRightarrow \ln \mathrm{RP}^{+}$ & 0.117 & 0.890 \\
\hline $\operatorname{lnRP^{-}} \nRightarrow \ln \mathrm{MP}^{+}$ & 5.026 & 0.010 \\
\hline $\operatorname{lnMP}^{+} \nRightarrow \ln \mathrm{RP}^{-}$ & 0.337 & 0.715 \\
\hline $\ln \mathrm{WP}^{+} \nRightarrow \ln \mathrm{MP}^{-}$ & 6.800 & 0.002 \\
\hline $\ln \mathrm{MP}^{-} \nRightarrow \ln \mathrm{WP}^{+}$ & 0.354 & 0.704 \\
\hline $\ln \mathrm{WP}^{-} \nRightarrow \ln \mathrm{MP}^{-}$ & 1.041 & 0.361 \\
\hline $\ln \mathrm{MP}^{-} \nRightarrow \ln W \mathrm{P}^{-}$ & 2.488 & 0.093 \\
\hline $\operatorname{lnRP^{+}} \nRightarrow{\ln M P^{-}}^{-}$ & 2.116 & 0.131 \\
\hline $\operatorname{lnMP}^{-} \nRightarrow \operatorname{lnRP}^{+}$ & 2.367 & 0.104 \\
\hline
\end{tabular}




\begin{tabular}{|c|c|c|}
\hline $\ln R P^{-} \nRightarrow \ln \mathrm{MP}^{-}$ & 0.693 & 0.505 \\
\hline $\operatorname{lnMP^{-}} \nRightarrow \operatorname{lnRP^{-}}$ & 0.968 & 0.387 \\
\hline $\ln W \mathrm{P}^{-} \nRightarrow \ln W \mathrm{P}^{+}$ & 6.930 & 0.002 \\
\hline $\operatorname{lnWP^{+}} \nRightarrow \operatorname{lnWP^{-}}$ & 1.633 & 0.205 \\
\hline $\operatorname{lnRP^{+}} \nRightarrow \ln W P^{+}$ & 8.467 & 0.001 \\
\hline $\operatorname{lnWP^{+}} \nRightarrow \ln R P^{+}$ & 3.293 & 0.045 \\
\hline $\operatorname{lnRP^{-}} \nRightarrow \ln W P^{+}$ & 5.698 & 0.006 \\
\hline $\ln W P^{+} \nRightarrow \operatorname{lnRP^{-}}$ & 1.538 & 0.225 \\
\hline $\operatorname{lnRP^{+}} \nRightarrow \ln W P^{-}$ & 3.217 & 0.048 \\
\hline $\operatorname{lnWP^{-}} \nRightarrow \operatorname{lnRP^{+}}$ & 2.798 & 0.070 \\
\hline $\operatorname{lnRP^{-}} \nRightarrow \operatorname{lnWP^{-}}$ & 12.652 & 0.000 \\
\hline $\ln W P^{-} \nRightarrow \quad \ln R P^{-}$ & 0.910 & 0.409 \\
\hline $\operatorname{lnR} \mathrm{P}^{-} \nRightarrow \operatorname{lnRP^{+}}$ & 22.657 & 0.000 \\
\hline $\operatorname{lnRP^{+}} \nRightarrow \ln R P^{-}$ & 2.579 & 0.086 \\
\hline
\end{tabular}




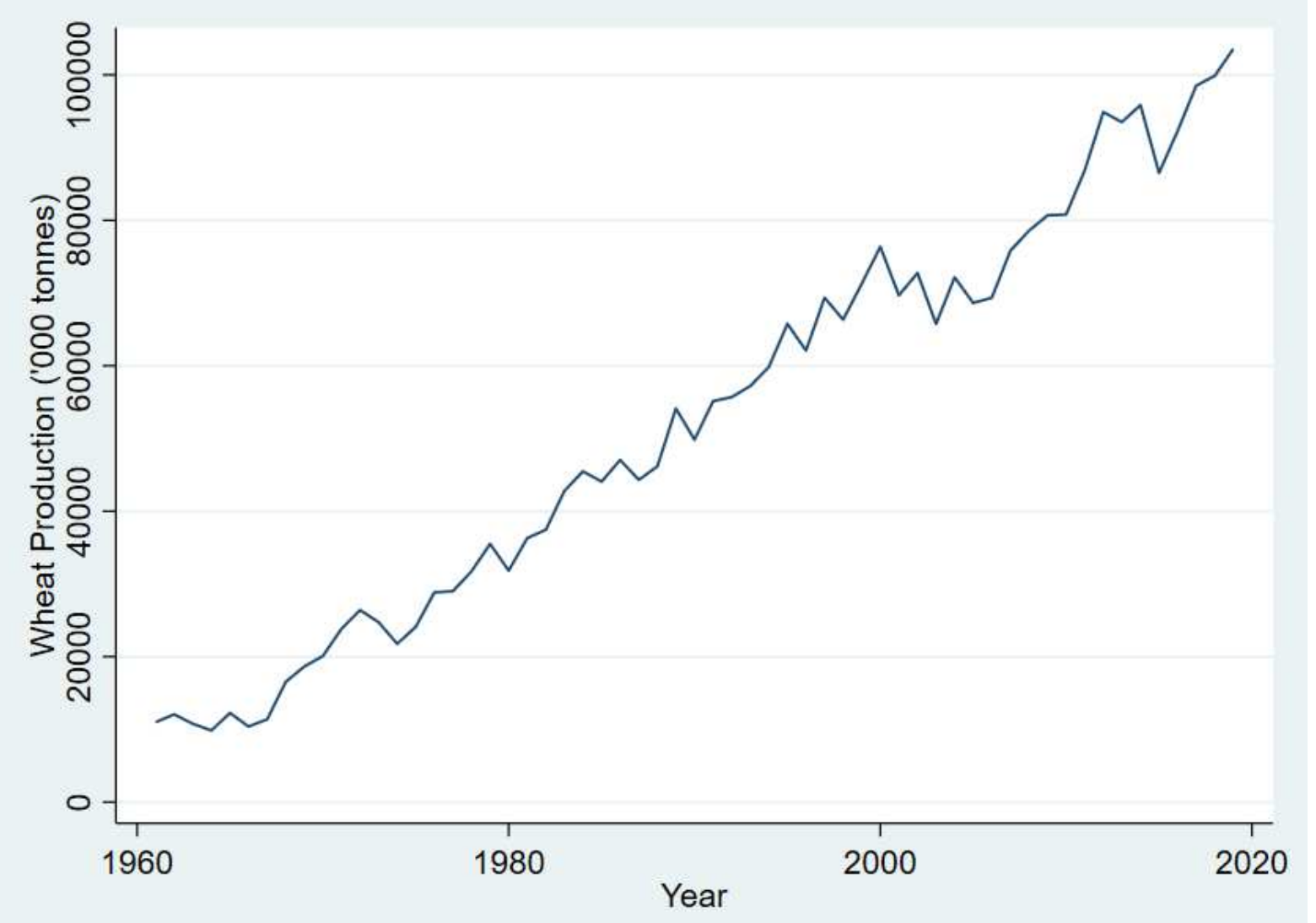

Figure 1. Trends of Wheat Production in India 


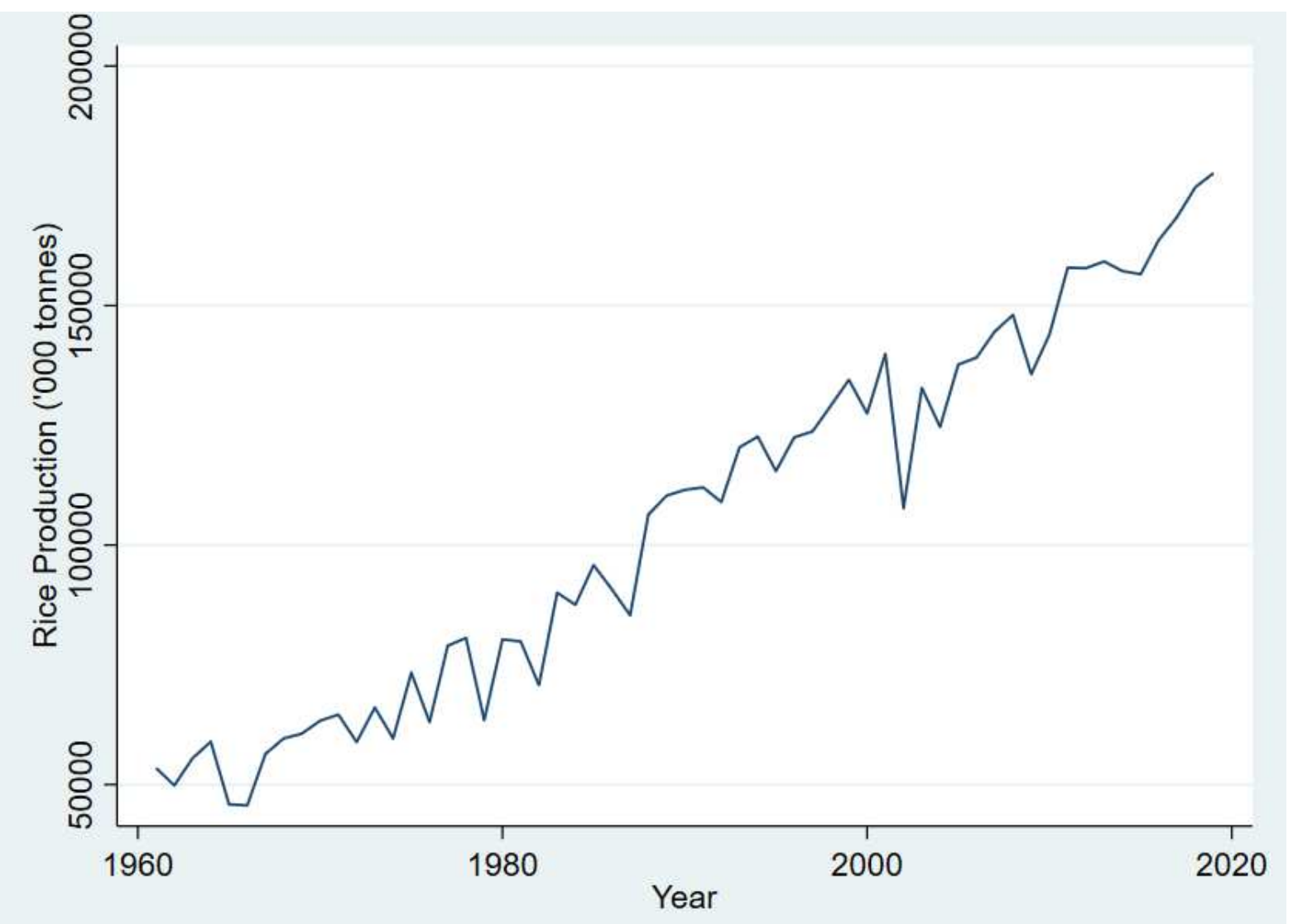

Figure 2. Trends of Rice Production in India 


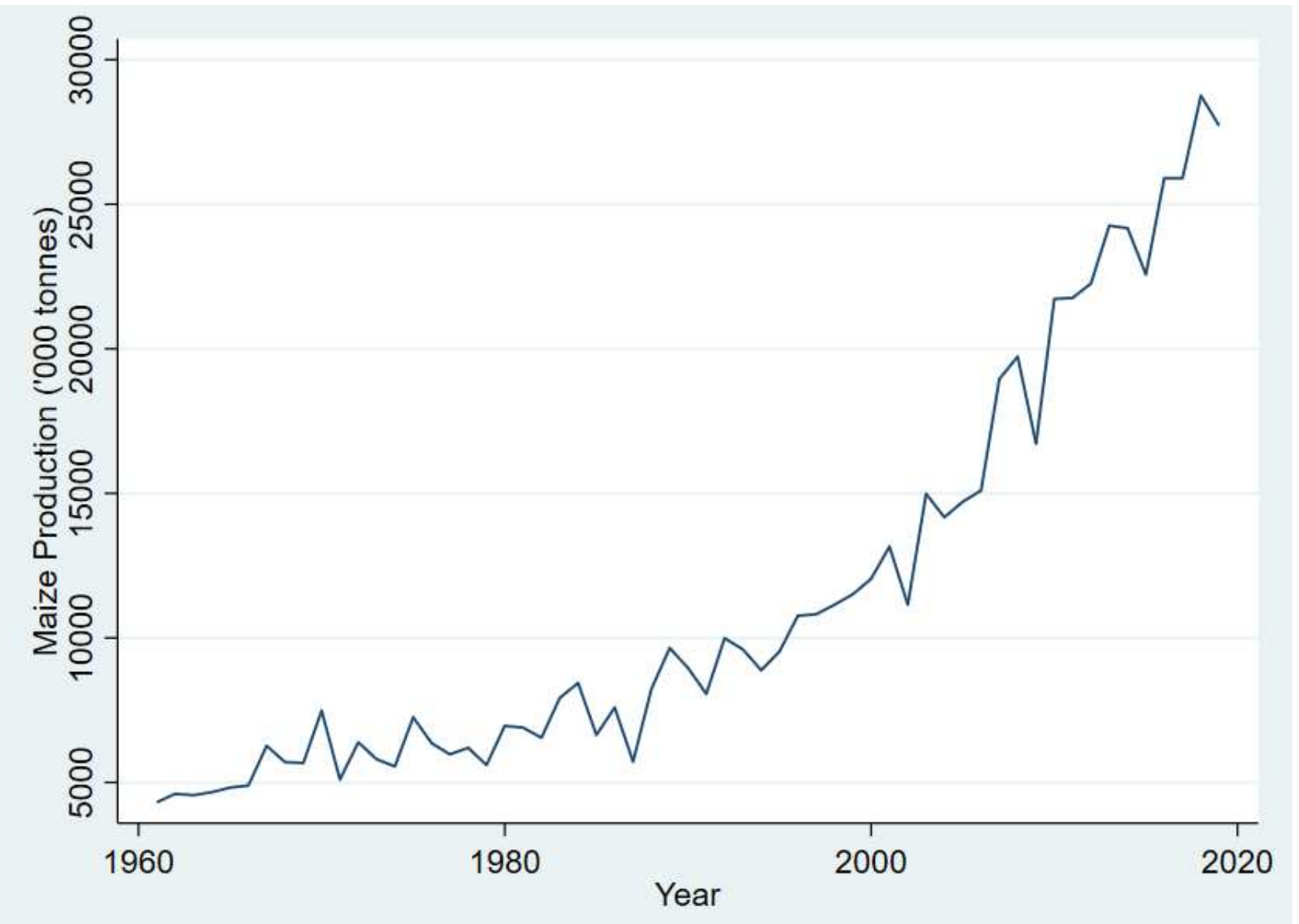

Figure 3. Trends of Maize Production in India 


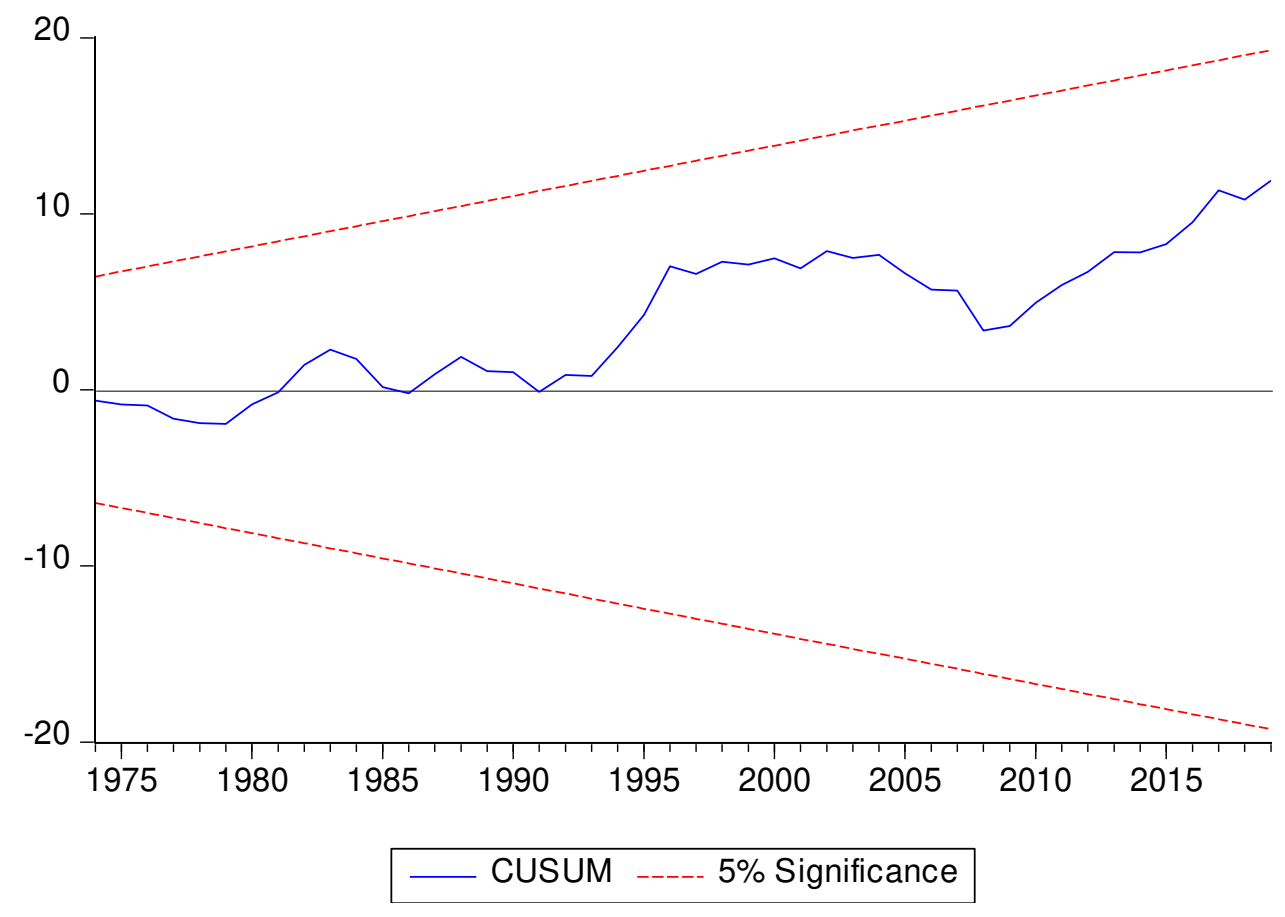

Figure 4. CUSUM Plot

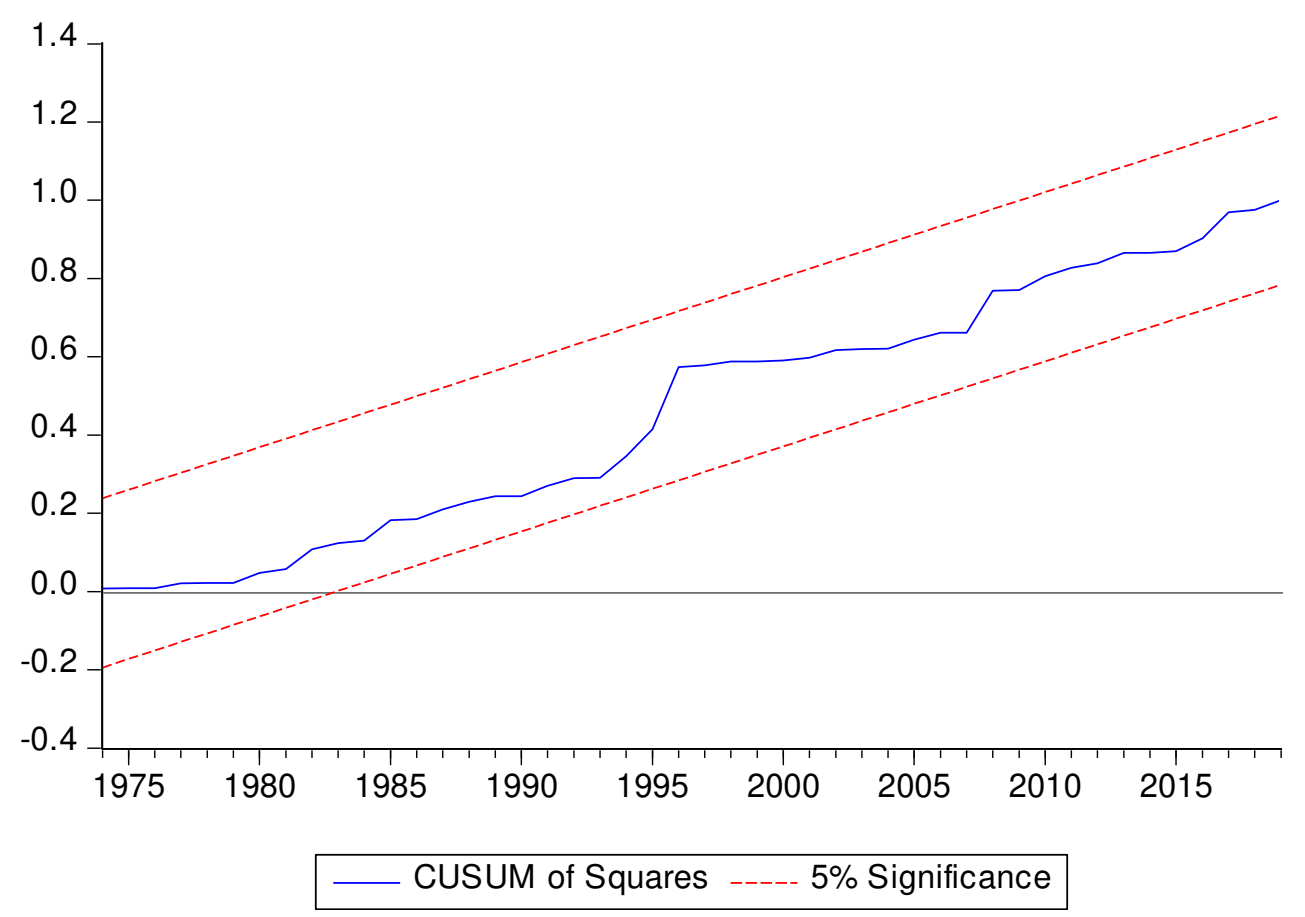

Figure 5. CUSUM Square Plot 
Figures

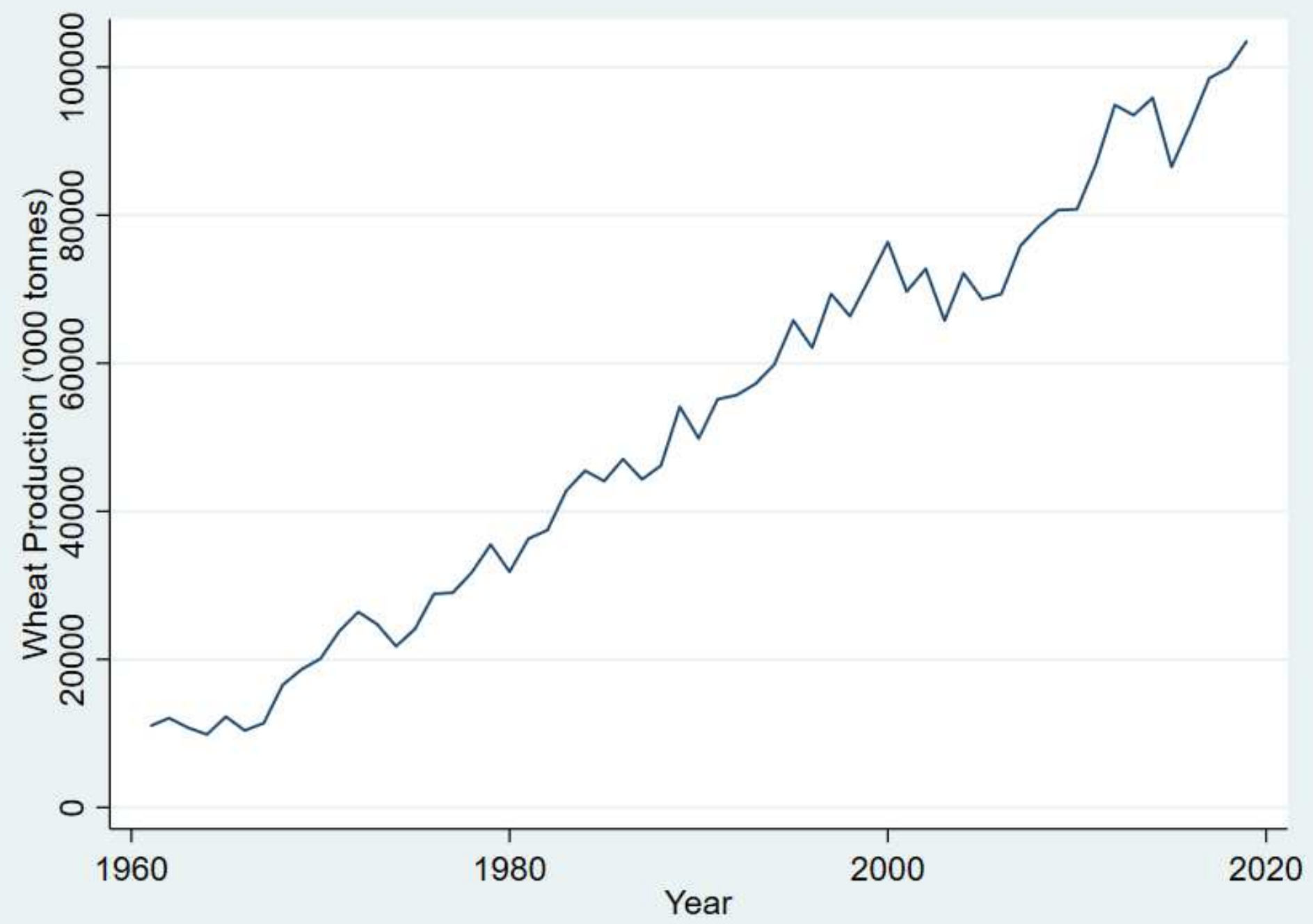

Figure 1

Trends of Wheat Production in India 


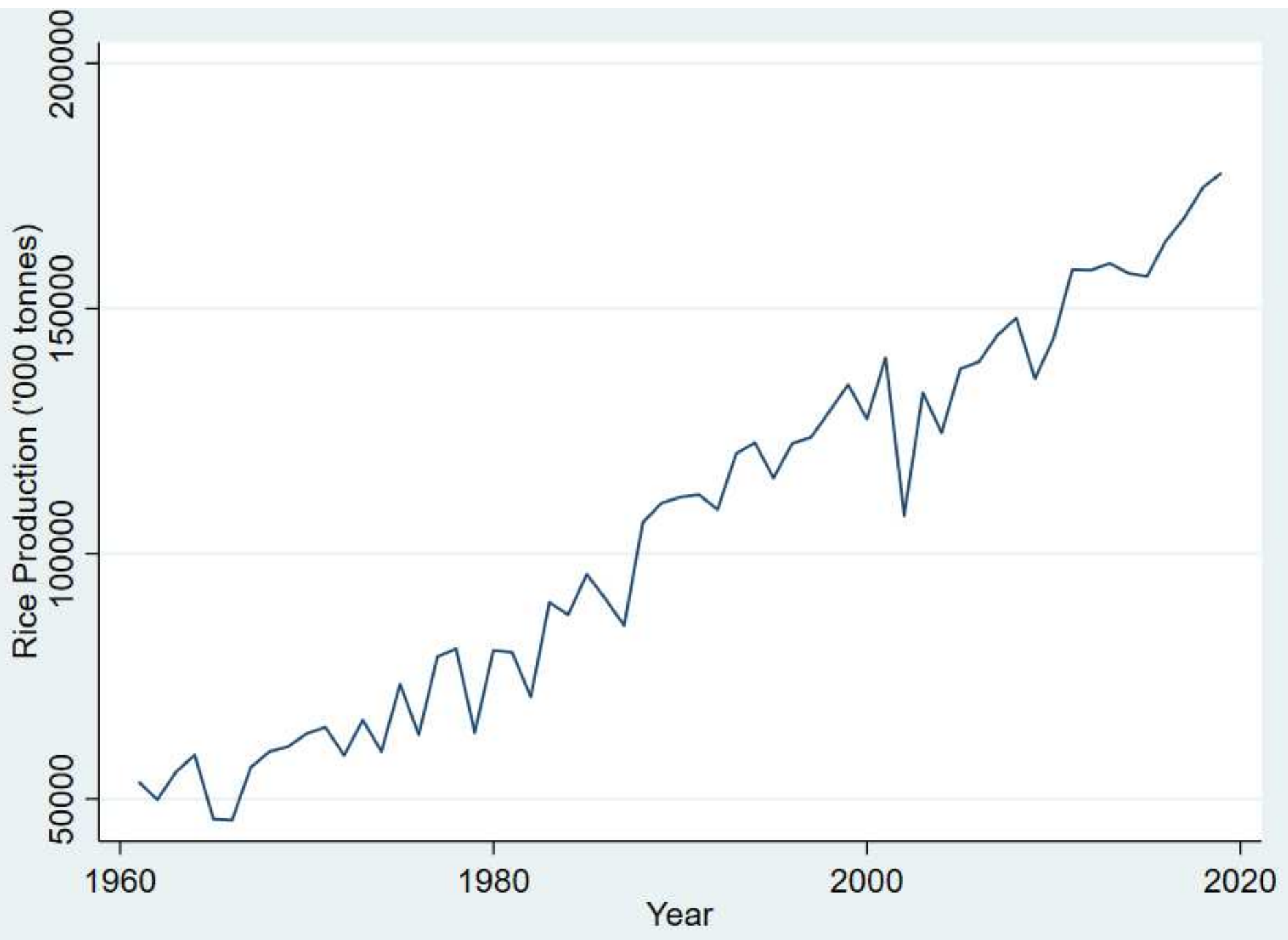

Figure 2

Trends of Rice Production in India 


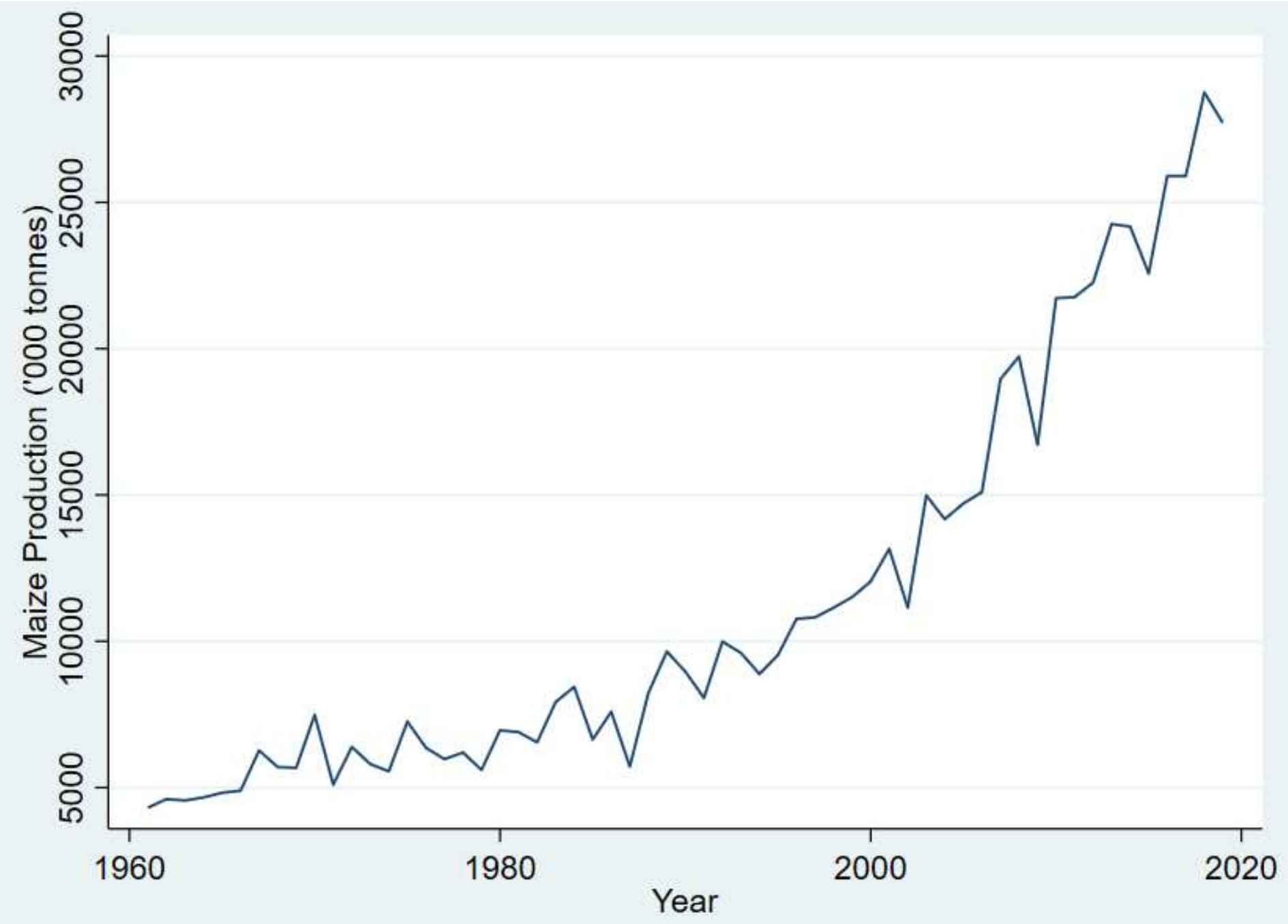

Figure 3

Trends of Maize Production in India 


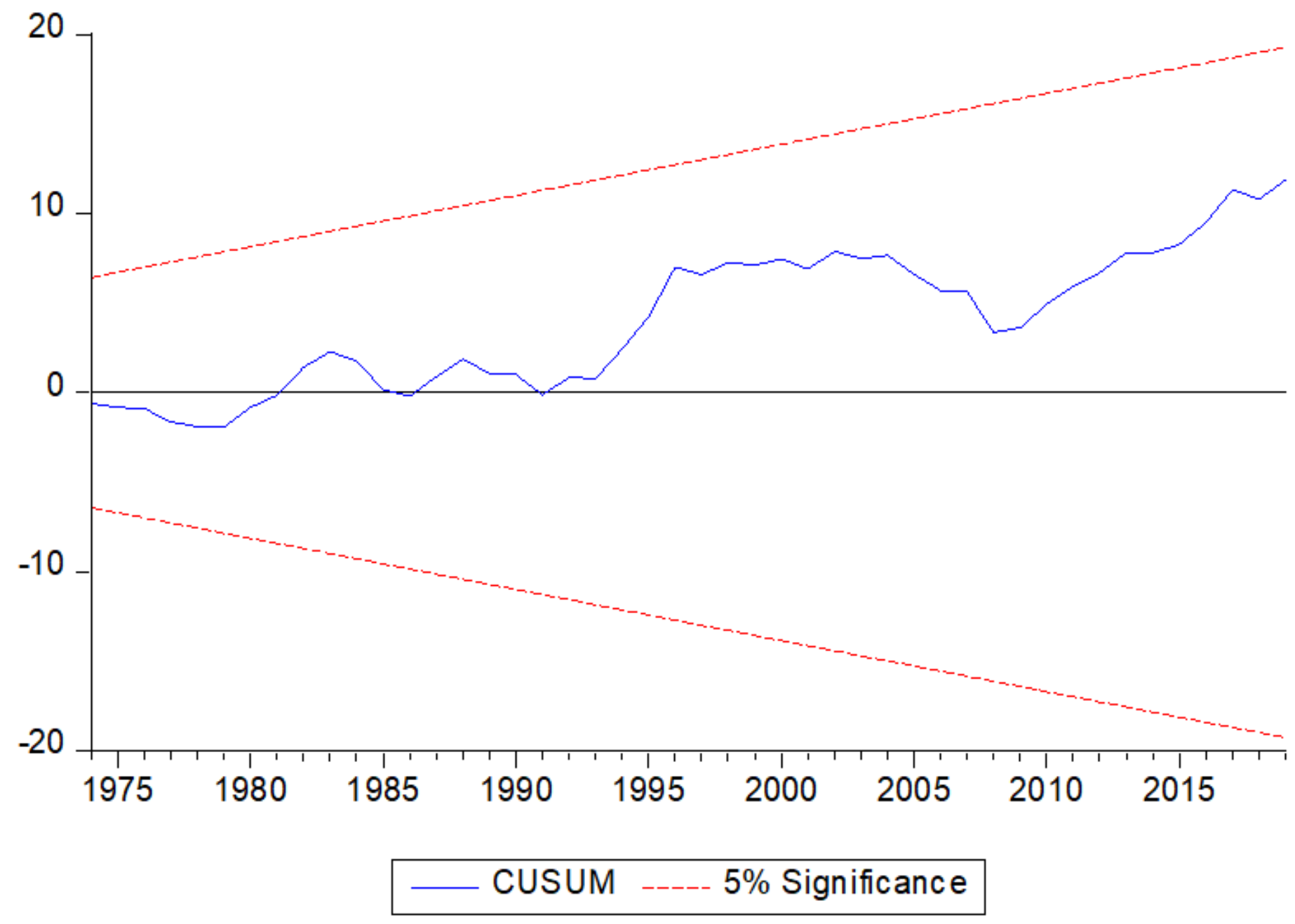

Figure 4

CUSUM Plot 


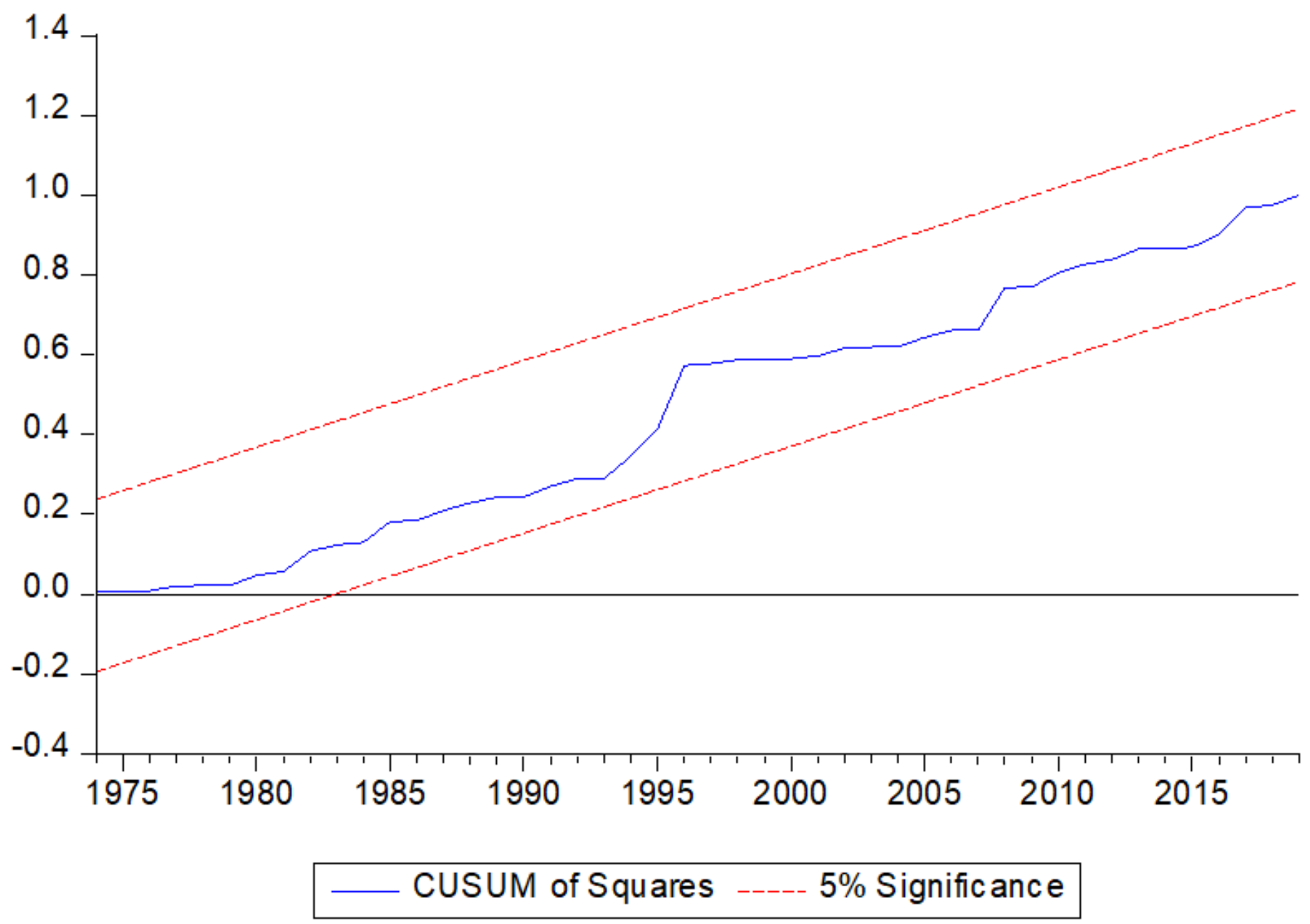

Figure 5

CUSUM Square Plot 